\title{
Review of Management Strategies of Constraints in Garlic (Allium sativum L.) Production
}

\author{
G. Diriba-Shiferaw ${ }^{1}$ \\ Received : $27^{\text {th }}$ January $2016 /$ Accepted : $29^{\text {th }}$ June 2016
}

\begin{abstract}
The main aim of this review is to provide an overview of the garlic crop productivity and its production management requirements like soil, climate and fertilization in general and specifically in Ethiopia, comparing them with current research trends and to indicate future benefits of soil nutrient management investigations and their importance for agronomic and cultural practices. This paper reviewed that application of balanced nutrients under optimum moisture availability in different soil types is an important crop management strategy, which may help maximizing crop yield and quality. Also, lack of optimum nutrients and moisture in the soil has been the major bottlenecks of garlic production and productivity; since the crop has a very shallow root system that requires frequent irrigation and fertilization with different types of fertilizers under various soil types. Low soil fertility is one of the principal and pervasive constraints to garlic production in Ethiopia; thus, there are differences among soil types in yielding ability under different nutrients and soil characteristics. Most smallholder farmers in Ethiopia appreciate the value of fertilizers, but they are seldom able to apply them at the recommended rates and at the appropriate time according to the soil characteristics. These are because of high cost, lack of credit, delivery delays, and low and variable returns. In addition, the traditional organic inputs, crop residues and animal manures, identified that it cannot meet crop nutrient demand over large areas because of the limited quantities available, the low nutrient content of the materials, and the high labor demands for processing and application. However, there was felt that could exist an opportunity to increase garlic crop yields through identification/selection of soil type and balanced nutrients application or searching for other nutrients sources beyond Urea and Diammonium phosphate especially in Ethiopian condition. Therefore, the integrated use of both the organic and inorganic fertilizers continuum inputs was felt the best option to increase both yield potential and quality of garlic crop and environment-friendly sustainable farming systems and increase of profit margins for growers.
\end{abstract}

Keywords: Bulb crops, garlic productivity, nutrients, organic and inorganic fertilizers, soil and climate requirements, soil types, yield and quality

\section{INTRODUCTION}

Increasing agricultural productivity in Ethiopia is a means both to improve the livelihoods of rural people and the sustainability of the economy as agriculture is the main stay of more than $80 \%$ of the Ethiopian population and accounts for $40 \%$ of the Gross domestic product (GDP) of the country (IWMI, 2010). Although
Ethiopia has potentially abundant irrigable land and water resources, its agricultural system does not yet fully benefit from irrigated agriculture and the technologies of water management and land utilization. As a result, agricultural productivity in Ethiopia is very low. The main factor behind this is low uptake of inputs like 
fertilizers by farmers due to the unreliable moisture availability and nutrients deficiency in consequence of low and variable rain fall patterns and land degradation. Hence, it is believed that, these production constraints should be reduced using secured access to irrigation and efficient utilization of farming lands. Accordingly, expansion of irrigated agriculture and integrated fertilizers utilization are the main focuses of the food security strategy in the growth and transformation plan of the country (GTP, 2010). Garlic is one of the main Allium vegetable crops known worldwide with respect to its production and economic value which requires good production and management practices. It is used as a seasoning in many foods worldwide and without garlic, many of our popular dishes would lack the flavor and character that make them favorites. However, the quality and high yield garlic production is depend on production and management practices on both field and after harvested.

Despite its importance and increased production, garlic yield and quality is affected by various biotic and abiotic stresses, among which low and/or excess mineral nutrition, irrigation schedule or rainfall are among the major ones (Jaleel et al., 2007; Cheruth et al., 2008). Garlic crop has a shallow root system and needs optimum and regular application of water and nutrients. Cropping season and soil moisture may affect the quality and yield of garlic; low moisture conditions in the soil are conducive to poor yields (Shock et al., 1998), while excessive soil moisture results in wastage of irrigation water, nutrients leaching, and may lead to rots and poor bulb quality. The crop yields varied considerably among sites and among production seasons at the same site. These variations were probably due to soil, cropping season, amount and type of nutrients available, planting date, degree of plant population and other differences in cultural practices. In dry cropping season, water is the most important limiting factor in agriculture and economic development issues. Water is an important factor in reducing yield and one way to increase the crop yield is using irrigation water; thus, its application must be done efficiently to ensure profitability through maximizing yield, because as a natural resource it is either inadequate or irregular in most areas where onions production is prevalent (Muhammad et al., 2011).

With the adoption of new technology of intensive cropping with high yielding varieties, there is a considerable demand on soil for supply of nutrients. Fertilizer types and/or rates also affect the productivity and quality of bulb crops. Weak vegetative growth, poor bulb formation, undesirable crop quality and low nutritional quality result from inadequate levels of the primary nutrients namely: nitrogen, phosphorus and potassium (Liu et al., 2010). In many crop producing areas lack of available nutrients is frequently one of the most limiting factors due to continuous cultivation of the land and degradation of soils. The average nutrient depletion in East Africa, particularly in Ethiopia is estimated to be around 47 to $88 \mathrm{~kg} \mathrm{ha}^{-1}$ year $^{-1}$ in general, and $100 \mathrm{~kg} \mathrm{ha}^{-1}$ year $^{-1}$ in particular on the highlands (Henao and Baanante, 1999). Major factors contributing to such depletion are soil erosion, fixation of $\mathrm{P}$ and leaching of $\mathrm{N}, \mathrm{K}$, and $\mathrm{S}$; the problem is further accelerated by deleterious land use practices resulting from high population pressure. As garlic plant require and sensitive to a variety of elements for growth and development, the deficiency of these elements is manifested in the detrimental effects on the growth and development of the plant (Tisdale and Nelson, 1985). Also Mattew et al., (2000) and Havlin et al., (2007) stated that Zinc showed high sensitivity in production of onions. Thus, this review paper was concentrated more on the identification of different management strategies of constraints in garlic production.

\section{Garlic Crop and Its Productivity}

The genus Allium, which belongs to the family Alliaceae, is diverse and comprises about 750 species; but only seven of them are widely 
cultivated in different parts of the world. Of these, the species important in Ethiopia are onion (Allium cepa L.), shallot (Allium cepa var. ascalonicum L.), garlic (Allium sativum L.) and leek (Allium ampeloprasum L.). The first three are diploid with the basic chromosome number of $2 n=16$ whereas leek is teteraploid with $2 n=32$ (Jones, 1990; Currah and Rabinowitch, 2002). Garlic is one of the main Allium vegetable crops known worldwide with respect to its production and economic value. It is one of the oldest cultivated vegetables and the second most widely produced Allium next to onion (Rubatzky and Yamaguchi, 1997; Hamma et al., 2013; Hassan, 2015).

Garlic is used as a seasoning in many foods worldwide; without garlic, many of our popular dishes would lack the flavor and character that make them favorites. Garlic's volatile oil has many sulphur containing compounds that are responsible for the strong odor, its distinctive flavor and pungency as well as for its healthful benefits (Salomon, 2002). Moreover, it contains considerable amounts of minerals like $\mathrm{Ca}, \mathrm{P}$ and $\mathrm{K}$, and its leaves are sources of protein, vitamin A and C (Maly et al., 1998). Garlic has higher nutritive value than other bulb crops: $30-35 \%$ dry matter, $6-7 \%$ protein, $0.2 \%$ lipid, $23-28 \%$ carbohydrate, $0.7-0.9 \%$ fiber, $1.1-1.4 \%$ ash matter and vitamins, especially $\mathrm{B}_{1}, \mathrm{~B}_{2}, \mathrm{~B}_{6}$ and C. Garlic also contains antibiotics garlicin and allistatin, a number of enzymes, amino acids, universal substances, including trace elements (Maly et al., 1998). Economic significance of garlic in Ethiopia is quite considerable; it is grown as spice and used for flavouring local dishes, and contributes to the national economy as export commodity (Fekadu and Dandena, 2006). Production of cash crops like garlic and other spices is proved to be income generating activity for farmers, especially for those who have limited cultivated land or small holder farmers (FAO, 2006).

Garlic has a wide area of adaptation and cultivation throughout the world. On a global scale, leading producers are China, India, Korea, Egypt, Thailand and Spain. In some countries like China, garlic production exceeds dry onion production. Majority of the garlic is produced in Asia (87\%), China and India, being the largest producers, collectively accounting for $78 \%$ of the production but in Africa accounting only $2.8 \%$ of the total world production. However, the yield produced in China (23.08 $\mathrm{t} \mathrm{ha}^{-1}$ ) was more than four times higher than the yield observed in India (5.27 $\left.\mathrm{t} \mathrm{ha}^{-1}\right)$ and higher than the world mean (16.71 t ha-1) (FAOSTAT data, 2011). World area coverage by garlic was increased from $1,142,220$ ha in 2003 to $1,422,408$ ha in 2011 with an average productivity of 12 and $16.71 \mathrm{t} \mathrm{ha}^{-1}$, respectively (FAO, 2003; FAOSTAT, 2011). In Ethiopia, garlic is one of the important bulb crops produced for home consumption and is a sources of income to many peasant farmers in many parts of the country (Metasebia and Shimelis, 1998; Getachew and Asfaw, 2000). Garlic production was increased from 6,042 ha in 2001/02 to 21,258 ha of land in 2012/13 with a total production increment from 79,421 to 222,548 tonnes of bulbs, but its productivity was decreased from 13.20 and $10.47 \mathrm{t} \mathrm{ha}^{-1}$, respectively (CACC, 2002; CSA, 2012/13). The yield differences exhibited by the Ethiopia from the developed countries most likely reflect differences in technological resources and aspects related to the management of the crop, rather than to differences in genetic background and performance of the cultivars used. The bulk of garlic for domestic market is produced in homestead gardens of subsistence farmers especially in Ambo, Debrework, Adiet, Sinnana and many other areas of Ethiopian highlands, and characterized by low yields of about 11.7 t ha $^{-1}$ (CSA, 2010) and in East showa about $11.31 \mathrm{t} \mathrm{ha}^{-1}$ (CSA, 2012/13). Out of the total production, greater than $58 \%$ was used for household consumption, $24.5 \%$ for market and $16 \%$ for seed. In this country, garlic is used as ingredient of local stew 'wot' and for formulation of local medicines (CSA, 2010).

Of the total production of Alliums in the 
country, Ethiopia, the area coverage of garlic in $2007 / 2008$ was $9,316.90$ ha, and total production was about 103,541.68 tonnes of bulbs, which was produced by 1,490,681 landholders (CSA, 2008). Garlic accounts for $0.06 \%$ of area and $0.62 \%$ of yield from the total private peasant holdings of 'Meher' season temporary crops in the country. In 2009/2010, CSA (2010) reported that national garlic cultivated land was 15,361 ha owned by 2.079 million landholders. Among vegetable crops it ranks second in the number of landholders next to Ethiopian cabbage (2.799 million landholders), but it leads in productivity; garlic about $11.69 \mathrm{t} \mathrm{ha}^{-1}$ and Ethiopian cabbage about $8.36 \mathrm{t} \mathrm{ha}^{-1}$. Garlic is produced mainly in the mid and high lands of the country (Getachew and Asfaw, 2000; CACC, 2002) and the bulk of garlic for domestic market is produced in homestead gardens of subsistence farmers and produced mainly as a cash crop to earn foreign currency by exporting it.

Despite its importance and increased production, garlic productivity, in many parts of the world, is low due to genetic and environmental constraints affecting its yield and yield related traits (Nonnecke, 1989). In Ethiopia, small growers in the highlands grow garlic traditionally but due to obsolete cultural practices, yields are generally low (ENAIA, 2003). Diverse crop management problems and the nature of propagation accounted for the low yield of garlic in Ethiopia; major production constraints include lack of proper planting material (improved varieties), inappropriate agronomic practices, absence of proper pest and disease management practices and marketing facilities, and lower soil fertility status in many soil types particularly $\mathrm{N}$ and $\mathrm{P}$ nutrients (Getachew and Asfaw, 2000).

\section{Climate and Soil Requirements of Garlic Crop}

Garlic is the most widely cultivated Allium species in Ethiopia and it has a wide range of climatic and soil adaptation. Climatically, regions with a reasonably mild winter with some rainfall followed by a sunny dry summer, which is good for maturity and harvesting the bulbs, are ideal for garlic production (Brewster, 1994; Lemma and Herath, 1994). Rubatzky and Yamaguchi (1997) indicated that garlic plants are very hardy and tolerate low, even some freezing temperatures, although in some areas of extreme cold it may not survive the winter. Garlic production occurs in most countries ranging from the equator to about the $50^{\circ}$ latitude and grows best within the range of $12-24{ }^{\circ} \mathrm{C}$ temperature (Nonnecke, 1989). High temperatures are required for bulb development, but cooler conditions in the early stages favor vegetative growth and elevations from 500-2000 meters above sea level provide suitable growth condition (Rice et al., 1990). Excessive humidity and rainfall are detrimental to the vegetative growth and bulb formation. Insufficient moisture and water logging easily stress plants. So, to attain maximum yield, moisture in the top $30 \mathrm{~cm}$ of soil should be maintained close to field capacity for growth (Brewster, 1994; Rubatzky and Yamaguchi, 1997).

The seasonal and annual variations in rainfall severely impede agricultural productivity in general and garlic production in particular. Even though, irrigation is available in all areas, it requires a huge financial and capital investment; as a result, rain fed agriculture may continue to play a major role in the near future, especially in areas with sufficient rainfall. Bulb crops require a supplemental irrigation where rainfall is insufficient (Tilahun et al., 2011).

Garlic is a high-value crop, which requires rich soil, good drainage, friable soil-preferably with high organic matter content, and water should not be deficient during bulb formation until two weeks before harvesting time. Excess supply of water two weeks before harvesting time affects the storage quality and the crop prefers a soil with a $\mathrm{pH}$ of 6.5-7.5 as it is sensitive to higher acidity (Bachmann, 2001; Potgieter, 2006). The most suitable soil types for garlic crop growth 
are sandy loam to sandy clay loam, and very fine sandy loam (silts) soils, deep mineral topsoil, well drained muck soils and relatively high (greater than 2.0\%) in organic matter are ideally suited for growing bulb. The crop produces a coarse rooting system, whilst requiring a degree of firmness for good root to soil contact; the soil must be free from compaction and well drained. Under poor soil drainage, bulbs become discolored and under clay loam soil conditions, the bulbs are deformed and difficult to harvest (Crop specific protocol number 52).

From the various soil types found in Ethiopia, Cambisols (12\%), Vertisols (9\%), Fluvisols (7\%), Nitosols (6\%) and Andosols (1\%) are the most important agricultural soils (FAO, 1986). The two soil types found in Debre Zeit area are Andosols and Vertisols with an organic matter content of about $2.05 \%$ and $1.89 \%$, respectively (M'Nen, 1992). Andosols (light gray soil) have well-drained properties, relatively higher organic matter, and nutrients $(\mathrm{N}, \mathrm{K}$ and some micronutrients) content as compared to Vertisols. The higher sand content of Andosols is more important for bulb growth and easily expansion in the soil, but it has a characteristic of fixing nutrients particularly phosphorus, which led to unavailability of the nutrient for the crop (Wakene et al., 2002). According to M'Nen (1992), Vertisols are highly productive in the area; however, drainage and management of the soil is cumbersome. Covering about 8 million ha in the highlands, Vertisols are considered suitable for cereals, pulses as well as for vegetables. However, their low N supply capacity and meager organic matter content coupled with their severe water logging problems limit their productivity (Teklu and Teklewold, 2009). The crop requires thoroughly prepared soil seedbed by repeated ploughing and light irrigation before planting the crop with a welldecomposed FYM application at the rate of 10 to $20 \mathrm{t} \mathrm{ha}^{-1}$ (FAO, 2003). Soils with high organic matter content are preferred due to their increased moisture and nutrient-holding capacity, and less proneness to crusting and compaction (Bodnar et al., 1998). The application of organic fertilizers assist structuring of clay soil to open and admit air penetration to roots and drainage, both conditions necessary for satisfactory plant growth (Eimhoit et al., 2005).

\section{Nutrient Requirements of Garlic Crop}

A sustainable agricultural system is one that is economically viable, provides safe, nutritious food, and conserves resources and enhances the environment (Campbell et al., 2004).

Fertilizers are the basis to produce more crop output from existing land under cultivation (Ryan, 2008). The economic and environmental implications of excessive nutrient use by crops calls for balanced fertilization and that nutrient needs of crops is according to their physiological requirements and expected yields (Ryan, 2008). Fertilizer requirements of garlic crop vary with fertility status of the soil, availability of soil moisture, variety of the crop, purpose for which the crop is grown, etc. Of many factors, fertility status of the soils significantly affecting garlic crop yield. The three major essential plant nutrients, N, P and $\mathrm{K}$ are increasingly in short supply in the soils of many African countries because of the large quantities taken up from the soil relative to the other essential nutrients (Chien and Menon, 1995; Marschner, 1995; Rao et al., 1998), which is true also for many Ethiopian soils (Yohannes, 1994). Soil fertility studies conducted at different locations in Ethiopia for different crops have shown significant yield responses to applied nitrogen and phosphorus fertilizers, indicating that most of the Ethiopian soils are deficient in nutrients, especially $\mathrm{N}$ and $\mathrm{P}$ (Asnakew and Tekalign, 1991; Berga et al., 1994; Yohannes, 1994).

Bulb crops are high value crops and their improved yield and quality are important economic considerations and they are more susceptible than most crop plants in extracting nutrients, especially the immobile types, because of their shallow and unbranched root system; hence, they require and often respond well to 
additional fertilizers (Brewster, 1994). Garlic has a moderate to high fertilizer requirement, depending on the nutrient status of the soil (Berga et al., 1994).

Today, efforts to obtain higher yields of garlic have led to the application of various types of fertilizers. The different types of fertilizers have dissimilar concentrations of plant nutrients and therefore affect the soil environment differently. As humankind strives to obtain higher yields of garlic through heavy application of fertilizers, such procedures must equally preserve the quality of the crop (Cantwell et al., 2006). Bulb crops are a heavy feeder, requiring ample supplies of $\mathrm{N}, \mathrm{P}$, and $\mathrm{K}$ in either the form of inorganic or organic fertilizers or a combination of them. Sub-optimal levels of these nutrients in the soil adversely affect the yield, quality and storability of bulbs (Gubb and Tavis, 2002).

\section{The use of mineral fertilizers in garlic production}

Nitrogen $(\mathrm{N})$ is a vitally important raw material required for the growth of plants, as it is an essential constituent of metabolically active compounds such as amino acids, proteins, enzymes, coenzymes and some non-proteinous compounds (Biswas and Mukherjee, 1993). On the other hand, extensive use of N-based fertilizers worldwide has resulted insignificant environmental problems associated with highinput agricultural production systems. The pollution of natural resources and rising costs of $\mathrm{N}$ fertilizers has also focused greater attention to improve their use in agriculture and created the development of improved $\mathrm{N}$ use efficient crop plants (Vitousek et al., 1997; Raun and Johnson, 1999; Good et al., 2004).

On the other hand, smallholder farmers in Ethiopia are known to use low rates of inorganic nitrogen and phosphorus fertilizers (less than 100 $\mathrm{kg} \mathrm{ha}^{-1}$ of urea and/or DAP) for crop production due to prohibitively high prices (Morris et al., 2007; Demere and Gebrekidan, 2008; Tesfaye et al., 2011). The low application of inorganic fertilizers to crops may stem from reluctance of farmers to apply fertilizers due to anticipated low response of the crop because of climatic uncertainty (particularly erratic rainfall) during the main growing season (Morris et al., 2007). It may also be attributed to lack of knowledge as to which kinds and rates of fertilizers are recommended for their specific crops, soils, and agro-climatic conditions (Vlek, 1990); or to existence of disparities in access to fertilizers or purchasing power among farmers as a result of varied resource endowments (Murage et al., 2000; Morris et al., 2007). Farmers apply also low amounts of organic fertilizers owing to competing needs such as the use of cow dung as a source of energy for cooking and crop residues as feed for animals (Morris et al., 2007).

The total amount of $\mathrm{N}$ required for crops will vary with the soil type, the previous crop grown, and the amount of organic matter present in the soil and the climatic conditions during the growing season. Kakar et al., (2002) reported that $\mathrm{N}$ accounts for a higher percentage of the variation in plant height, leaf area, leaf count, and fresh and dry plant mass when it was increased from 50 to $200 \mathrm{~kg} \mathrm{ha}^{-1}$. Garlic will generally require $70-125 \mathrm{~kg} \mathrm{~N}^{-1}$ and onehalf of it should be applied as soon as the crop begins to grow; the remainder should be split into two to three applications at three-week intervals and should be completed within 4-6 weeks in the California, USA (Bodnar et al., 1998). The production of vigorous sprouts is one of the most important factors of successful garlic production (Potgieter, 2006). Adequate application of $\mathrm{N}$ during sprouting stage and application of different sources and rates of $\mathrm{N}$ play an important role in the production of vigorous vegetative and optimum leaf expansion of crops and influences bulb size produced (Stork et al., 2004). Excessive application of $\mathrm{N}$ at a late vegetative stage of garlic crop can limit yields and increases storage losses, while inadequate $\mathrm{N}$ can hasten maturity and limit yield (Batal et al., 1994). It is best not to apply $\mathrm{N}$ when the bulbs are beginning to enlarge since 
it will encourage excessive leaf growth and reduce bulb size (Bachmann, 2001).

Nitrogen and phosphorus are among the most important and frequently applied nutrients as mineral fertilizers for producing most crops in Ethiopia. However, the rates of application of the nutrients are far less than the requirements and based on blanket recommendations on different areas and soils (Fikreyohannes, 2005). However, the crop nutrient requirements vary with species, variety, soil type and season, a blanket recommendation of $92 \mathrm{~kg} \mathrm{ha}^{-1} \mathrm{~N}$ and $\mathrm{P}_{2} \mathrm{O}_{5}$ each of $\mathrm{N}$ and $\mathrm{P}$ fertilizer are in using for garlic production in many areas of Ethiopia (Yohannes, 1994). Kilgori et al., (2007) reported similarly a significantly increased cured bulb yield of garlic with increased $\mathrm{N}$ from 0 to 60 and $120 \mathrm{~kg} \mathrm{ha}^{-1}$. However, they found that higher dosage of 180 and $240 \mathrm{~kg} \mathrm{~N} \mathrm{ha}^{-1}$ reduced the bulb yield. At Samaru (Nigeria), Babaji (1994) observed that $\mathrm{N}$ application increased almost all growth and yield parameters of garlic significantly with a maximum yield of $15 \mathrm{tha}^{-1}$ at $90 \mathrm{~kg} \mathrm{~N} \mathrm{ha}^{-1}$.

Phosphorus deficiency is one of the largest constraints to crop production in many tropical soils, owing to low native contents and high P fixation capacity of the soil (Barber, 1995; Norman et al., 1995; Fairhust et al., 1999). Phosphorus is essential for root development and when the availability is limited, the growth of plant can be reduced. It is involved in several physiological and biochemical processes in plant maturity, fruit setting and seed production (Tsidale et al., 1993; Miller and Donanue, 1995). It is part of plant nucleoprotein and hence important in plant heredity and also plays a role in cell division, stimulates root growth, and hastens plant maturity and physiologically notable in the storage and transfer bonds of ATP. The need for $\mathrm{P}$ is critical during the early stage of growth when normal meristem development and rapid height growth are necessary for a high yield (Tisdale et al., 1993). The movement of $\mathrm{P}$ in soils is very low and its uptake generally depends on the concentration gradient and diffusion in the soil near roots (McPharlin and Robertson, 1999).

In onions, $\mathrm{P}$ deficiencies reduce root and leaf growth, bulb size and yield and can delay maturation (Greenwood et al., 2001). In soils that are moderately low in $\mathrm{P}$, garlic growth and yield can be enhanced by applied P. Results of long-term fertilizer trials on loamy sand soils in Germany have shown a strong response of onions to $\mathrm{P}$ fertilization in the range $0-52 \mathrm{~kg}$ $\mathrm{P}$ ha $^{-1}$ (Alt et al., 1999). Depending on yield levels, $\mathrm{P}$ uptake rates in onion estimated to be about 15-30 kg ha-1 (Pire et al., 2001; Salo et al., 2002). In western Kenya, as reported by Jamma (1998) soil, water and nutrient losses tremendously reduced by $\mathrm{P}$ addition because of the rapid formation of soil cover. Application of $\mathrm{P}$ from 29 to $48 \mathrm{~kg} \mathrm{P} \mathrm{ha-1}$ can usually be adequate for better garlic production while in the desert areas, however, rates of P up to $96 \mathrm{~kg}$ $\mathrm{P} \mathrm{ha}^{-1}$ needed (Sims et al., 2003).

Vegetable production could be highly profitable, if the correct amount and type of fertilizer is applied and the crop species grown utilizes the fertilizer nutrients very efficiently (Anonymous, 2002). Application of phosphoric fertilizers generally has a great impact on crop yields because $\mathrm{P}$ deficiency limits the response of plants to other nutrients, especially on highly weathered and leached soils of both tropical and temperate regions of the world where soil acidity causes infertility and general limitation to crop production (Alaam et al., 2002). Beside $P$ fertilizer management, soil type could significantly determine the efficiency of $\mathrm{P}$ use by specific crop species (Ezekiel and Adigun, 2005).

Best quality garlic can be produced through application of balanced fertilizers (Cantwell et al., 2006). Research work has been done on the base of NP in different soil types (Brewster, 1994; Lemma and Herath, 1994) and in various climatic conditions, but very limited work has 
been reported on various sources of fertilizers for a certain nutrient. Among the major macronutrients, potassium $(\mathrm{K})$ and sulphur (S) have been ignored by most of our local growers to apply to their crops (Berga et al., 1994; Yohannes, 1994). Though the quantity of $\mathrm{K}$ and $\mathrm{S}$ in most of the soils is adequate, there is also evidence of fixation of $\mathrm{K}$ and leaching of $\mathrm{S}$ in different types of soils (Murashkina et al., 2006). Therefore, the application of $\mathrm{K}$ and $\mathrm{S}$ to soils having even medium amounts of $\mathrm{K}$ and $\mathrm{S}$ contents may still show positive effects on plants (Potgieter, 2006). In addition, balanced application of nutrients can improve soil fertility and eliminate the effect of nutrient deficiencies beyond improving of garlic productivity and quality (Lujiu et al., 2004). Similarly, garlic growth, nutrients concentration and uptake by the crop, quality and postharvest shelf-life of garlic bulbs were significantly increased with integrated fertilization of the crop using different nutrients/elements (Diriba-Shiferaw et al., 2013a, 2013b; 2014).

Mineral fertilizers of balanced doses increased the leaf area, photosynthetic productivity, yield of garlic plant in particular, and resulted in substantial increases in crop production in general (Zhou et al., 2005). They investigated that fertilization of the soils in 12 trials on garlic and other vegetables with NPK, adding $60-120 \mathrm{~kg} \mathrm{~S} \mathrm{ha}^{-1}$, increased yields by 16.0 $36.4 \%$ and high vegetable quality and in nutrient management, $\mathrm{S}$ combined with other nutrients has to become a common fertilizer practice to guarantee optimal crop production as also reported by Shalini et al., (2002). The study undertaken on two soils types by DiribaShiferaw et al., (2015) also showed that the growth, yield and economic potential of garlic were increased in response to the combined application of $92 \mathrm{~kg} \mathrm{~N}+40 \mathrm{~kg} \mathrm{P}+30 \mathrm{~kg} \mathrm{~S} \mathrm{ha}^{-1}$ with a benefit cost ratio of 6.44:1 on Andosols and $138 \mathrm{~kg} \mathrm{~N}+40 \mathrm{~kg} \mathrm{P}+60 \mathrm{~kg} \mathrm{~S} \mathrm{ha}^{-1}$ with a benefit cost ratio of 5.86:1 on Vertisols. However, they concluded that application of $92 \mathrm{~kg} \mathrm{~N}+40$ $\mathrm{kg} \mathrm{P}+30 \mathrm{~kg} \mathrm{~S} \mathrm{ha}^{-1}$ combination along with 140 $\mathrm{kg} \mathrm{ha}^{-1} \mathrm{KCl}$ fertilizer on both soils are optimum and economical to attain better productivity of garlic crop to enhance household income and livelihoods of the farmers in the study areas.

Onions take up $\mathrm{K}$ in quantities nearly equivalent to N (Pire et al., 2001; Singh and Verma, 2001; Salo et al., 2002). Moreover, like N, K is easily leached from soils and fertilization may be needed for high yields (Brewster, 1994; Marschner, 1995). The K requirement of onion plants increases with yield and its functions are linked to photosynthesis (Greenwood and Stone, 1998). If $\mathrm{K}$ is deficient or not supplied in adequate amounts, bulb plants can be stunted, become susceptible to disease and have reduced yields (Rizk, 1997; Singh and Verma, 2001). Yield responses of onions to applied $\mathrm{K}$ would be less likely on soils with high cation exchange capacity such as certain types of clay soils, low soil moisture contents and low yielding cultivars (Marschner, 1995; Boyhan and Hill, 2001; AlMoshileh, 2002).

Like other macronutrients, sulphur is a vital nutrient for life and essential for plant growth. It contributes to high crop yields and quality in three different ways: 1) it provides a direct nutritive value; 2 ) it improves the use efficiency of other essential plant nutrients, particularly $\mathrm{N}, \mathrm{P}$ and some micronutrients, like $\mathrm{Zn}, \mathrm{Fe}, \mathrm{Cu}$, $\mathrm{Mn}$ and $\mathrm{B}$; and 3) it improves crop product quality by increasing protein and oil percentage in seeds, cereal quality for milling and baking, nutritional value and marketability of vegetables and fruits. In general, $\mathrm{S}$ has similar functions in plant growth and nutrition as $\mathrm{N}$ and plant requirements for $\mathrm{S}$ are comparable to $\mathrm{P}$. Most crops remove 15 to $25 \mathrm{~kg} \mathrm{~S} \mathrm{ha}^{-1}$. Oil crops, legumes, forages, and some vegetables (onions) require more $\mathrm{S}$ than $\mathrm{P}$ for optimal yield and quality (Fan and Messick, 2007).

Significant increases remained restricted up to $30 \mathrm{~kg} \mathrm{~S} \mathrm{ha}^{-1}$ even though application up to $45 \mathrm{~kg}$ $\mathrm{S}$ ha ${ }^{-1}$ consistently increased fresh and the dry yield of garlic bulbs (Jaggi and Raina, 2008). 
Surendra (2008) also reported an increase in bulb yield of $3.78 \mathrm{t} \mathrm{ha}^{-1}$ in onion and $1.88 \mathrm{t}$ $\mathrm{ha}^{-1}$ in garlic with higher $\mathrm{S}$ use efficiency due to the application of $\mathrm{S}$ up to $40 \mathrm{~kg} \mathrm{ha}^{-1}$ over the recommended dose of NPK fertilizers. Being sulphur loving crop, sulphur response in garlic is natural and expected. Consequently, significantly increased garlic growth, bulb and foliage yields and other yield and quality attributes of the plant following sulphur application within the range of 20 to $60 \mathrm{~kg} \mathrm{ha}^{-1}$ was reported by different scholars (Nagaich et al., 2003; Losak and Wisniowska-kielian, 2006; Diriba-Shiferaw et al., 2015).

\section{Integrated use of organic and inorganic fertilizers}

The use of balanced sources of nutrients to obtain high yield and good quality garlic bulbs is an important practice in today's garlic production. Organic inputs are often proposed as alternatives to mineral fertilizers. However, the farmers' organic inputs, crop residues and animal manures cannot meet crop nutrient demand over large areas because of the limited quantities available, the low nutrient content of the materials, and the high labor demands for processing and application. Therefore, most farmers in Africa fall within the two extremes of the organic to inorganic fertilizer continuum and use a combination of organic and inorganic inputs (Palm et al., 1997). Complementary use of chemical fertilizers and organic manures has assumed great importance nowadays to maintain as well as sustain a higher level of soil fertility and crop productivity (Shalini et al., 2002). Farmyard manure (FYM) is among the important soil amendments to which farmer's access has in mixed farming systems as it improves both crop productivity, and the physical and chemical conditions of soils through supplying different nutrients and organic matter (Harendra et al., 2009; Alam et al., 2010). The widespread use of FYM greatly depends, among others, on proper application methods, which increase the value, reduce costs, and enhance effectiveness
(Islah, 2010). Manures rich in potash like wood ash and poultry manure giving an increased outturn. Well-rotted FYM is applied at the rate of 25-50 $\mathrm{t} \mathrm{ha}^{-1}$ after the first ploughing or it may preferably be applied to the preceding crop (Shrestha, 2007).

Both manure and chemical fertilizers have a potential role on the growth and development of crops (Shalini et al., 2002). The application of FYM at the rate of $20 \mathrm{tha}^{-1}$ increased garlic bulb yield significantly with increased uptake of $\mathrm{N}$, $\mathrm{P}$ and $\mathrm{K}$ nutrients; the $\mathrm{S}$ and FYM application showed synergistic interaction effect on the uptake of S and ultimately on the bulb yield of garlic; maximum bulb yield was obtained at 40 $\mathrm{kg} \mathrm{S}$ ha $^{-1}$ with 20 t FYM ha-1 (Harendra et al., 2009). In Ethiopia, Fisseha (1983) reported application of $20 \mathrm{tha}^{-1}$ of biogas sludge and $20 \mathrm{t}$ FYM ha-1 to be the optimum level in increasing the size and weight of onion bulbs at Debre Zeit and Awassa areas. Similarly, Melaku (2010) reported that application of $20 \mathrm{t} \mathrm{FYM} \mathrm{ha-1}$, with $80 \mathrm{~kg} \mathrm{~N} \mathrm{ha}^{-1}$ and $20 \mathrm{~kg} \mathrm{P} \mathrm{ha}^{-1}$ could ensure optimum total bulb yield of onion at Alage, Ethiopia. Teklu and Teklewold (2009) reported that the application of one season $2 \mathrm{t} \mathrm{FYM} \mathrm{ha-1}$ and inorganic fertilizers of $61 \mathrm{~kg} \mathrm{~N} \mathrm{ha}^{-1}$ and $31 \mathrm{~kg} \mathrm{P} \mathrm{ha}^{-1}$ produced the highest bulb yield of shallot. Similarly, the application integrated chicken manure (CM) and inorganic fertilizers $(\mathrm{N}$ and $\mathrm{P}$ ) at a combination rates of $46 \mathrm{~kg} \mathrm{~N}+$ $20 \mathrm{~kg} \mathrm{P}+10 \mathrm{t} \mathrm{CM} \mathrm{ha}^{-1}$ on both Andosols and Vertisols of Ethiopia significantly increased the growth, yields and qualities of garlic and also significantly reduced the amount of $\mathrm{N}$ and $\mathrm{P}$ fertilizers by about $50 \%$ as compared to the levels of inorganic fertilizers previously recommended for the crop (Diriba, 2014).

Intensive cropping, imbalanced fertilization and absence of application of micronutrients, less or no use of organic manures could result in the depletion of soil fertility (Samuel, 1981; Palm et al., 1997). According to the report of Alam et al., (2010), the response of onion to micronutrients in terms of growth and yield in calcareous 
soils increased over the control treatment. The combination of zinc and boron increased the maximum bulb yield by $49.66 \%$ over the control and on the other hand, $\mathrm{Zn}$ and $\mathrm{B}$ alone increased the bulb yield of onion by $28.64 \%$ and $27.74 \%$ over the control, respectively. Garlic plants showed differential response to different rates of compound fertilizers; significantly superior response of garlic, as observed by the vegetative growth, nutrients content and uptake of the crop, and bulb yield and quality was obtained when garlic planted in Andosols with the fertilization of D-coder compound fertilizer at the rate of $200 \mathrm{~kg} \mathrm{ha}{ }^{-1}$ which supplied $28 \% \mathrm{~N}+18 \% \mathrm{P}+42 \% \mathrm{~S}+0.2 \% \mathrm{Zn}$ nutrients combination (Diriba-Shiferaw et al., 2013a,b). In addition, integrated soil fertility management could enhance sufficient uptake of nutrients by crops (Poornima, 2007). According to Poornima, (2007) higher concentrations of $\mathrm{N}, \mathrm{P}, \mathrm{K}$ and $\mathrm{S}$ in onion plant were recorded in treatments received higher levels of $\mathrm{K}$ and $\mathrm{S}$, which in turn resulted in higher uptake of $\mathrm{N}, \mathrm{P}$, $\mathrm{K}$ and $\mathrm{S}$, by onion crop.

\section{Effect of Pre-harvest Factors on Postharvest Quality and Shelf Life of Garlic}

Many external and internal factors influence both post harvest quality and shelf life of crops. According to Baligar et al., (2001) external factors such as soil moisture, temperature, light, management practices, soil biological, and fertilizer materials, and their interactions with genetic, morphological, and physiological plant traits have profound effects on yield and qualities of crops. Types and rates of nutrients with varieties have great impacts on post harvest shelf life of bulb crops. Sprouting is the major factor limiting storage life of garlic bulbs (Kang and Lee, 1999; Cantwell et al., 2003). At harvest, bulbs are in a state of innate dormancy and dormancy terminates when inner sprout growth begins (Brewster, 1987). High dose of N produces quick sprouting of thick-necked bulbs during storage. Moreover, greater percentage of open thick-necked bulbs results in increased sprouting due to increased access of oxygen and moisture to the central growing point. In Ethiopia, Kebede, (2003) and Gebrehaweria, (2007) found that bulbs fertilized with higher amounts of $\mathrm{N}$ exhibited less storability with more weight loss compared to the shallot and garlic bulbs fertilized with lower amounts of N. Another factor that could be attributed to the increment in sprouting of bulbs is higher concentration of growth promoters than inhibitors in the bulbs of $\mathrm{N}$ fertilized plants that keep it growing (Dankhar and Singh, 1991). Timing and types of various fertilizer applications have been reported to have effects on disease incidence, weight loss, and regrowth in storage (Rabinowitch and Brewster, 1990).

A dry matter or total solids content is an important quality factor in many crops. Dry matter measurements also provide information on environmental factors and cultural management procedures during the production season (Ruthford and Wittle, 1982). Dankhar and Singh (1991) investigated the effect of nitrogen and potash on the total sugar composition of different varieties of onions and found that the total sugar of bulbs decreased during storage and the reduction was higher at lower dose of nitrogen compared to its higher dose. Total sugar content during storage is considered an index of keeping quality. Changes in the carbohydrate composition of bulbs during storage were reported where the main change was the hydrolysis of oligosaccharides to reducing sugars (Rutherford and Whittle, 1982). Salama et al., (1988), while evaluating storage methods for onions, observed that bulb quality decreased most rapidly when onions were stored in air at $10{ }^{\circ} \mathrm{C}$ as indicated by lower concentration of sugars and greater pungency. After eight weeks, fructose levels increased rapidly and this was attributed to low temperature hydrolysis of fructans (Darbyshire, 1978). Garlic grown on soils with balanced fertilizers and subsequent management of growth and postharvest practices recorded better bulb qualities with long storability. D-coder compound fertilizer at 
the rates of 200 and $400 \mathrm{~kg} \mathrm{ha}^{-1}$, which supplied $\mathrm{N}, \mathrm{P}, \mathrm{S}$, and $\mathrm{Zn}$ nutrients, recorded higher percent of dry matter, total soluble solids and pungency of bulbs and lower percent in weight and diameter losses during three months of storage times (Diriba-Shiferaw et al., 2013b).

Bulbs of onion, garlic and shallot are routinely stored for varying lengths of time before being marketed. Even though the bulbs may be dormant during this time, flavor changes have been measured in bulbs and its pungency was found to play a very important role in the storage of bulbs (Randle and Lancaster, 1995). Flavor intensity and quality do change in storage and the changes appear to be dependent on cultivar, storage duration, depth of bulb dormancy, and storage temperature. Jones and Bisson (1964) reported that a mild, high moisture (low solids) onion had lower storage quality than pungent, low moisture (high solids) onions.

Surface discoloration, moisture loss, and microbial spoilage contribute to loss of shelf life and quality in peeled garlic cloves (RamirezMoreno et al., 2001). Other important causes of quality loss are sprouting and rooting, which occur because of high humidity conditions in plastic packaging and because of storage at higher than the recommended $0-2^{\circ} \mathrm{C}$ (Cantwell et al., 2003).

\section{Post Harvest Handling and Bulb Storage Conditions of Garlic Crop}

Vegetables, especially perishable ones need good handling and storage conditions after harvesting. In this regard, bulb crops are highly deteriorated in their quality otherwise curing of bulbs should take place as it serves several functions. First, it dries the outer two to four scales providing mechanical protection, limit entry of rot-causing organisms into still fleshy pseudostems or injured tissues, limit gas exchange; both effluent and intake of moisture, oxygen and carbon dioxide and giving an attractive appearance. It also dries those roots remaining attached to the bulb following undercutting and seal up the neck left attached to the crown following topping, deterring disease infection (Currah and Proctor, 1990). Lastly, curing encourages dehydration and sealing of wounds that may have occurred during bulb growth or mechanical damage. All these are to bring down the metabolism of the bulbs and promote mechanical damage dormancy (Davis and Isenberg, 1978). Curing also allows the leaves to naturally senesce, and substances in the leaves that inhibit sprouting and promote resistance to disease-causing fungi enter down into the bulbs (Rabinowitch and Brewster, 1990; Currah and Rabinowitch, 2002).

Garlic, which is not being sold fresh, needs to be cured prior to storing. Careful drying and curing prior to storage are crucial to prevent losses. In addition, careful handling and the choice of a suitable storage method for the cultivar type in question are vital to ensure that the product retains its quality until it reaches the consumer. Bulbs have natural storage organs well adapted for long-term crop storage. "Cosmetic quality", i.e. retaining an attractive appearance, is of increasing importance in competitive retail markets (Gubb and Tavis, 2002). At small scale level, simple, naturally ventilated storage structures constructed from poles, wire meshes and grass thatched roofing oriented to the direction of prevailing wind, can effectively be used for extending the shelf life of bulbs. Racks or tiers having two or three layers of bulbs would be desirable for proper storage (Gubb and Tavis, 2002).

The most important consideration here is that garlic should be thoroughly matured, cured and dried before storage. The essentials of successful storage are through ventilation, a uniform and comparatively low temperature, low humidity, proper maturity and freedom from disease infection. Aspergillus fumigates and Pencillium species frequently occur in the micro flora of stored temperate onions, but the former flourish only at greater than $40{ }^{\circ} \mathrm{C}$ and the later at $1-5^{\circ} \mathrm{C}$ or $20-25^{\circ} \mathrm{C}$ (Satti and Lopez, 1994). 
The climatic conditions of the storage area also influence the bulb shelf life in storage. Garlic respiration rate are generally low, but related exponentially to increased storage temperature between 0 and $20{ }^{\circ} \mathrm{C}$ and is generally a good indication of postharvest quality degradation (Peiris et al., 1997). Relative humidity has a large influence on storage life; sometimes its influence is greater than that of temperature. For long storage time, the optimum range of relative humidity is $50-60 \%$ and favorable temperature ranges from 0 to $5{ }^{\circ} \mathrm{C}$, which can be stored for 6-9 months depending on cultivar and species. They also must have good air circulation such as an open tray or a mesh bag, and refrigerator-storing causes looses of flavor very quickly and are subject to sprouting, due to the cool temperature and higher humidity (Satti and Lopez, 1994). Forms and purposes of bulbs storage also determine the quality and shelf life of garlic crops. Bulbs selected for planting stock are usually stored, with the dry tops attached in unheated warehouses and whole bulbs stored much better than individual cloves (Anonymous, 2004).

\section{CONCLUSION}

Bulb crop species grown worldwide are popular for their numerous purposes in many countries including Ethiopia for many years. Garlic crops are of importance in many diets, because of their nutritional significances and major economic and dietary importance to small-scale farmers; in addition to fresh consumption, the production of dried and processed garlic products for use in food preparation and as dietary health-food supplements is an important industry. The productivity and area of most of the crops grown in many parts of Ethiopia are declining due to soil degradation and the constraints of moisture and nutrients unavailability accompanying it and other poor management/cultivation practices. However, farmers continue growing crops in spite of obtaining low yields as a result of having little choices as producing the crops are vital for meeting their nutritional and economic needs. As a result, integrated soil fertility management is valuable to the plants for higher yield potential, bulb quality and environment-friendly sustainable farming systems and increase of profit margins for growers along with good moisture maintaining in the growing soils.

\section{REFERENCES}

Alaam, S.M., Latif, A., \& Zafar, I. (2002). Wheat yield and phosphorus use efficiency as influenced by method of phosphorus and zinc application. Pakistan Journal of Scientific and Industrial Research. 45, 117-119.

Alam, M.N., Abedin, M.J., \& Azad, M.A.K. (2010). Effect of micronutrients on growth and yield of onion under calcareous soil environment. International Research Journal of Plant Sciences. $1(3), 56-61$.

Al-Moshileh, A.M. (2002). Effect of rate and time of nitrogen application on onion production in the central region of Saudi Arabia. Journal of King Saud University. 14(1), 33-41.

Alt, D., Ladebusch, H., \& Melzer, O. (1999). Long-term trial with increasing amounts of phosphorus, potassium and magnesium applied to vegetable crops. Acta Horticulture, 506, 29-36. http://dx.doi.org/10.17660/ActaHortic.1999.506.2

Anonymous. (2002). Nutrient Deficiency Symptoms in Rice. Better Crops Intl. 2-25. 
Anonymous, (2004). GARLIC (organic) - Allium sativum, Factsheet, Ministry of Agriculture, Fisheries and Food Industry Competitiveness Branch, British Columbia. Pp 1-12. (http:// www.gourmetgarlicgardens.com/chemistry.htm)

Asnakew, W. \& Tekalign, M. (1991). Soil fertility management studies on wheat in Ethiopia. Debre Zeit Agricultural Research Center, Ethiopia. Pp 137-173.

Babaji, B.A. (1994). Effect of plant spacing and nitrogen fertilization on growth and yield of garlic. An M.Sc. Thesis submitted to the Post-graduate School. ABU, Zaria.

Bachmann, J. (2001). Organic Garlic Production. National sustainable agriculture information service. Davis, California, USA. (http://attra.ncat.org/attra- Pub/PDF/garlic.pdf)

Baligar, V.C., Fageria, N.K., \& He, Z.L. (2001). Nutrient Use Efficiency in Plants. J. Comm. Soil Sci. Plant Analysis, 32(7), 921 - 950. http://dx.doi.org/10.1081/CSS-100104098

Barber, S.A. (1995). Soil nutrient bioavailability. A mechanistic approach. John Wiley \& Sons, New York.

Batal, K.M., Bondari, K., Granberry, D.M., \& Mulinix, B.G. (1994). Effects of source, rate and frequency of $\mathrm{N}$ application on yield, marketable grades and rot incidence of sweet onion Allium L.C. Granex 33. Journal of Horticultural Science. 69(6), 1043-1051. http://dx.doi.or $\mathrm{g} / 10.1080 / 00221589.1994 .11516543$

Berga, L., Gebremedhin, W., Terrisa, J., Bereke-Tsehai, T., \& Yaynu, H. (1994). Potato Improvement Research. In: Herath E. and D. Lemma (eds.). Proceedings of the Second National Horticultural Workshop of Ethiopia. Addis Ababa, 1-3 December 1992. Institute of Agricultural Research and Food and Agriculture Organization. Addis Ababa, Ethiopia.

Biswas, T.D., \& Mukherjee, S.K. (1993). Textbook of Soil Science. (5 ${ }^{\text {th }}$ Ed.). Tata McGraw-Hill, New Delhi. Pp 170-197.

Bodnar, J., Schumacher, B., \& Uyenaka, J. (1998). Garlic Production. Agricultural and Rural Division. Davis, California, USA. (http://attra.ncat.gar/attra-Pub/PDF/garlic.pdf)

Boyhan, G.E., \& Hill, C.R. (2001). Preliminary evaluations of fertilization practices in short-day dry bulb onion production in southeast Georgia. HortScience, 36, 501.

Brewster, J.L. (1987). The effect of temperature on the rate of sprout growth and development within stored onion Bulbs. Annals of Applied Biology. 111, 463-465. http://dx.doi. org/10.1111/j.1744-7348.1987.tb01475.x

Brewster, J.L. (1994). Onions and other vegetable Alliums. CAB International, Wallingford, UK. Pp 236.

CACC (Central Agricultural Census Commission). (2002). Report on the preliminary result of area, production and yield of temporary crops (Meher season private peasant holdings). Part II. Ethiopian Agricultural sample Enumeration, (2001/2002). Federal Democratic Republic of Ethiopia, Central Statistical Authority, Addis Ababa. 
Campbell, C.A., Myers, R.J.K., \& Curtin, D. (2004). Managing nitrogen for sustainable crop production. Earth and Environmental Science, 42(1-3), 277-296.

Cantwell, M.I., Kang, J., \& Hong, G. (2003). Heat treatments control sprouting and rooting of garlic cloves. Postharvest Biology and Technology, 30, 57- 65. http://dx.doi.org/10.1016/ S0925-5214(03)00060-7

Cantwell, M., Voss, R., Hanson, B., May, D., \& Rice, B. (2006). Water and Fertilizer management for Garlic: Productivity, Nutrient and Water Use Efficiency, and Post harvest Quality. Report of a FREP Contact No. 97-0207.

Cheruth, A.J., Gopi, R., Sankar, B., Gomathinayagam, M., \& Panneerselvam, R. (2008). Differential responses in water use efficiency in two varieties of Catharanthus roseus under drought stress. Comptes rendus, Biologies, 331(1), 42-47. http://dx.doi.org/10.1016/S09255214(03)00060-7

Chien, S.H., \& Menon, G. (1995). Agronomic evaluation of modified phosphate rock products. Fertilizer Research, 41, 197-205. http://dx.doi.org/10.1007/BF00748309

CSA (Central Statistical Agency). (2008). Report on Area and Production of Crops (Meher season private peasant holdings). Volume I, Part III. Ethiopian Agricultural Sample Survey, (2007/2008). Federal Democratic Republic of Ethiopia, Central Statistical Authority, Addis Ababa. Statistical Bulletin 417. Pp 12-17.

CSA (Central Statistical Agency). (2010). Report on Farm Management Practices (Meher season private peasant holdings). Volume III, Part III. Ethiopian Agricultural Sample Survey, (2009/2010). Federal Democratic Republic of Ethiopia, Central Statistical Authority, Addis Ababa. Statistical Bulletin 468. Pp 10-19.

CSA (Central Statistical Agency). (2012). Report on area and production of crops (Meher season private peasant holdings). Volume IV, Part III. Ethiopian Agricultural Sample Survey, (2012/13). Federal Democratic Republic of Ethiopia, Central Statistical Authority, Addis Ababa. Statistical Bulletin 446. Pp 19-29.

Currah, L., \& Proctor, F.G. (1990). Onions in the Tropical Regions. Bulletin 35, Natural Resources Institute, UK.

Currah, L., \& Rabinowitch, H.D. (2002). Allium Crop Science: Recent Advances, CABI publishing, Pp. 329-515.

Dankhar, B.S., \& Singh, J. (1991). Effect of Nitrogen, Potash and Zinc on storage loss onion bulbs (Allium cepa L.). Journal of Vegetation Science. 18, 16-23.

Darbyshire, B. (1978). Changes in the carbohydrate content of onion bulbs stored for various times at different temperatures. Journal of Horticultural Sciences. 53(3),195-201. http://dx.doi.or $\mathrm{g} / 10.1080 / 00221589.1978 .11514819$

Davis, H.R., \& Isenberg, M.R. (1978). Storage recommendation for northern grown onions. Cornell university extension bulletin No. 148. Ithaca, New York. Pp 214. 
Demere, E., \& Gebrekidan, H. (2008). Economic Application Rates of Nitrogen and Phosphorus Fertilizers' for Maize Grown on Black Clay Soil (Vertisols) of Alemaya Areas, Ethiopia. Eth. Ethiopian Journal of Agricultural Economics. 7(1), 108 - 121.

Diriba, S.G. (2014). Response of Garlic (Allium sativum L.) to Fertilizer Management in Ada'a District, Central Highland of Ethiopia. A Ph.D. Dissertation Submitted to the School of Plant Sciences, School of Graduate Studies of Haramaya University, Ethiopia. Pp 90-155.

Diriba-Shiferaw, G., Nigussie-Dechassa, R., Woldetsadik, K., Tabor, G., \& Sharma, J.J. (2013a). Growth, and Nutrients Content and Uptake of Garlic (Allium sativum L.) as Influenced by Different Types of Fertilizers and Soils. Science, Technology and Arts Research Journal. 2(3), 35-50. http://dx.doi.org/10.5897/AJAR2013.7723

Diriba-Shiferaw, G., Nigussie-Dechassa, R., Woldetsadik, K., Tabor, G., \& Sharma, J.J. (2013b). Postharvest Quality and Shelf life of Garlic Bulb as Influenced by Storage Season, Soil Type and Different Compound Fertilizers. Journal of Postharvest Technology, 01(01), 069-083.

Diriba-Shiferaw, G., Nigussie-Dechassa, R., Woldetsadik, K., Tabor, G., \& Sharma, J.J. (2014). Bulb quality of Garlic (Allium sativum L.) as influenced by the application of inorganic fertilizers. Afr. J. Agric. Res., 9(8), 778-790. http://dx.doi.org/10.5897/AJAR2013.7723

Diriba-Shiferaw, G., Nigussie-Dechassa, R., Woldetsadik, K., Tabor, G., \& Sharma, J.J. (2015). Effect of Nitrogen, Phosphorus, and Sulphur Fertilizers on Growth, Yield, and Economic Returns of Garlic (Allium sativum L.). African Journal of Agricultural Research. 4(2), 10 22. http://dx.doi.org/10.4314/star.v4i2.2

Eimhoit, S., Schjonning, P., \& Munkholm, L.J. (2005). Soil aggregation - a matter of proper management. Danish Research Centre for Organic Farming. http://www.darcof.dk/enews/ jun05/crumb.html (accessed August 2008).

ENAIA (Ethiopian National Agricultural Input Authority). (2003). Crop Variety Register, Issue No.5. Pp 101-102.

Ezekiel, A.A., \& Adigun, I.O. (2005). Phosphorus-use Efficiency by Pepper (Capsicum frutescens) and Okra (Abelmoschus esculentum) at Different Phosphorus Fertilizer Application Levels on Two Tropical soils. Journal of Applied Sciences. 5(10), 1785-1791. http://dx.doi. org/10.3923/jas.2005.1785.1791

Fairhust, T., Lefroy, R., Mutert, E., \& Batjes, N. (1999). The importance, distribution and causes of phosphorus deficiency as a constraint to crop production in the tropics. Agroforestry Forum., 9, 2-8.

Fan, M.X., \& Messick, D.L. (2007). Correcting Sulphur Deficiency for Higher Productivity and Fertilizer Efficiency. IFA Asia-Pacific Crossroads in Bali, The Sulphur Institute (TSI), United States.

FAO (Food and Agriculture Organization). (1986). Soils Map of Ethiopia. FAO/UNDP/ $\mathrm{ETH} / 78 / 003$. Rome.

FAO (Food and Agriculture Organization). (2003). Global review of area and production of garlic, Pp 135-139. 
FAO (Food and Agriculture Organization). (2003). Optimizing soil moisture for plant production. FAO soils Bull., 79, 22-23. Food and Agriculture Organization of the United Nations, Rome.

FAO (Food and Agriculture Organization). (2006). Food security in Ethiopia, Agriculture and Consumer protection Department.

FAOSTAT (Food and Agriculture Organization of the United Nations Statistics). (2011) http:// faostat.fao.org/site/567/DesktopDefault.aspx?PageID=567\#ancor; 21/12/2013.

Fekadu, M., \& Dandena, G. (2006). Review of the status of vegetable crops production and marketing in Ethiopia. Uganda Journal of Agricultural sciences. 12(2), 26-30.

Fikreyohannes, G. (2005). Effect of Clove Size and Plant Density on the Bulb Yield and Yield Components of Garlic (Allium sativum L.) in Awabel Woreda, Eastern Gojjam Zone. M.Sc. Thesis Submitted to School of Graduate Studies of Alemaya University, Ethiopia. Pp 19-41.

Fisseha, G. (1983). The effects of alternative sources of organic fertilizers in increasing the yield of onions (Allium cepa L.). An M.Sc. Thesis presented to School of Graduate Studies of Addis Ababa University, Ethiopia. Pp 30-70.

Gebrehaweria, T. (2007). Effects of Mulching, Nitrogen and Phosphorus on Yield and Yield Components of Garlic (Allium sativum L.) at Alshaday, Eastern Zone of Tigray, Northern Ethiopia. An M.Sc. Thesis submitted to the School of Graduate Studies of Haramaya University, Ethiopia. Pp 22-62.

Getachew, T., \& Asfaw, Z. (2000). Achievements in shallot and garlic research report. No.36. Ethiopian Agricultural Research Organization, Addis Ababa. Ethiopia. Pp 43.

Good, A.G., Shrawat, A.K., \& Muench, D.G. (2004). Can less yield more? Is reducing nutrient input into the environment compatible with maintaining crop production. Trends Plant Sci., 9, 597-605. http://dx.doi.org/10.1016/j.tplants.2004.10.008

Greenwood, D.J., \& Stone, D.A. (1998). Prediction and measurement of the decline in the critical-K, the maximum $\mathrm{K}$ and total plant cation concentration during the growth of field vegetable crops. Annals of Botany, 82, 871-881. http://dx.doi.org/10.1016/j.tplants.2004.10.008

Greenwood, D.J., Stone, D.A., \& Barnes, A. (2001). Root development of vegetable crops. Plant and Soil, 68, 75-96. http://dx.doi.org/10.1007/BF02374729

GTP (Growth and Transformation Plan). (2010). The Federal Democratic Republic of Ethiopia five years Growth and Transformation Plan, 2010/11-2014/15, Sep. 2010, Addis Ababa, Ethiopia.

Gubb, I.R., \& Tavis, M.S.H. (2002). Onion pre-harvest and postharvest considerations. Pp. 237250. In: Rabinowitch, H.D., \& Currah, L. (eds.). Allim Crop Science. CABI publishing, UK. http://dx.doi.org/10.1079/9780851995106.0233

Hamma, I.L., Ibrahim, U., \& Mohammed, A.B. (2013). Growth, yield and economic performance of garlic (Allium sativum L.) as influenced by farm yard manure and spacing in Zaria, Nigeria. Journal of Agricultural Economics and Development, 2(1), 001-005. 
Harendra, S., Kumar, S.M., \& Singh, K.V. (2009). Effect of Sulphur and FYM on Yield and Nutrients Uptake by Garlic (Allium sativum L.) in an Alluvial Soil. Annals of Horticulture, 2(1), 86-88.

Hassan, A.H. (2015). Improving Growth and Productivity of two Garlic Cultivars (Allium sativum L.) Grown under Sandy Soil Conditions. Middle East Journal of Agriculture Research. 4(2), 332-346.

Havlin, J.L., Beaton, J.D., Tisdale, S.L., \& Nelson, W.L. (2007). An introduction to nutrient management. Soil Fertility and Fertilizers. Pp 244-289.

Henao, J., \& Baanante, C. (1999). Estimating rates of nutrient depletion in soils of agricultural lands of Africa. International Fertilizer Development Center (IFDC). Musck Shoals, Alabama USA. Pp. 76.

Islah, M. El-Hifny. (2010). Response of Garlic (Allium sativum L.) to some Sources of Organic Fertilizers under North Sinai Conditions. Research Journal of Agriculture and Biological Sciences 6(6), 928-936.

IWMI (International Water Management Institute). (2010). Irrigation potential in Ethiopia; Constraints and opportunities for enhancing the system.

Jaggi, R.C., \& Raina, S.K. (2008). Direct, residual and direct + residual effects of sulphur in garlic (Allium sativum L) - maize (Zea mays) cropping sequence. Journal of Environmental Biology. 29(1), 85-88.

Jaleel, C.A., Manivannan, P., Sankar, B., Kishorekumar, A., Gopi, R., Somasundaram, R., \& Panneerselvam, R. (2007). Water deficit stress mitigation by calcium chloride in Catharanthus roseus; effects on oxidative stress, proline metabolism and indole alkaloid accumulation. Colloids Surf. B: Biointerfaces, 60, 110-116. http://dx.doi.org/10.1016/j. colsurfb.2007.06.006

Jamma, B. (1998). Soil Fertility Replenishment Initiatives in Western Kenya: Soil Fertility Management Workshop (21-23 April 1998).

Jones, H.A., \& Bisson, C.S. (1964). Moisture content of different varieties of onions. Proceedings of the American Society for Horticultural Science, 31, 165-168.

Jones, R.N. (1990). Cytogenetics. In: Rabinowitch, H.D., and Brewster, J.L. (eds.), Onions and Allied crop Volume 1. Botany, Physiology and Genetics CRC Press, Inc. Boca Raton, Florida. Pp. 103-124.

Kakar, A.A., Abdullahzai, M.K., Saleem, M., \& Qaim Shah, S.A. (2002). Effect of Nitrogenous Fertilizer on Growth and Yield of Garlic. Asian Journal of Plant Sciences. 1(5), 544-545. http://dx.doi.org/10.3923/ajps.2002.544.545

Kang, J.S., \& Lee, D.S. (1999). Modified atmosphere packaging of peeled garlic cloves. Food Science and Biotechnology. 8, 68-71. 
Kebede, W. (2003). Shallot (Allium cepa var. ascalonicum) Responses to Plant Nutrients and Soil Moisture in a sub-humid Tropical Climate. Doctoral Thesis. Swedish University of Agricultural Sciences, Alnarp, 2003.

Kilgori, M.J., Magaji, M.D., \& Yakubu, A.I. (2007). Productivity of two Garlic (Allium sativum L.) Cultivars as Affected by Different Levels of Nitrogenous and Phosphorus Fertilizers in Sokota, Nigeria. American-Eurasian Journal of Agricultural \& Environmental Sciences. 2(2), 158-162.

Lemma, D., \& Herath, E. (1994). Agronomic Studies on Allium. Pp.139-145. In: Horticultural Research and Development in Ethiopia. 1-3 December 1992. Institute of Agricultural research and food and Agricultural Organization. Addis Ababa, Ethiopia.

Liu, W., Zhu, D., Liu, D., Geng, M., Zhou, W., Mi, W., Yang, T., \& Hamilton, D. (2010). Influence of nitrogen on the primary and secondary metabolism and synthesis of flavonoids in chrysanthemum morifolium ramat. Journal of Plant Nutrition. 33(2), 240-254. http://dx.doi. org/10.1080/01904160903434287

Losak, T., \& Wisniowska-Kieliam, B. (2006). Fertilization of garlic (Allium sativum L.) with nitrogen and sulphur. Annales Universitatis Mariae Curie Skodowska Section-E. Agricultura., $61,45-50$.

Lujiu, L., Xisheng, G., Qingsong, Z., Hongmin, X., \& Lin, Z. (2004). Balanced Fertilization Increases Garlic Yield in Anhui. Better Crops, 88(4), 30-35.

Maly, I., Bartos, J., Hlusek, J., Kopec, K., Peteikova, K., Rod, J., \& Spitz, P. (1998). Polni zelina_ stvi. Agrospoj Praha, 175-185.

Marschner, H. (1995). Mineral Nutrition of Higher Plants. $2^{\text {nd }}$ Edition. Academic Press, London, Harcourt Brace and Company. Pp 889.

Mattew, L.A., Wedell, A.N., Willium, D.P., \& John, H.P. (2000). Micronutrient status. Agronomy Journal. 92, 261-268.

McPharlin, I.R., \& Robertson, W.J. (1999). Response of onions (Allium cepa L.) to phosphate fertilizer placement and residual phosphorus on a Karrakatta sand. Australian Journal of Experimental Agriculture. 39, 351-359. http://dx.doi.org/10.1071/EA98145

Melaku, F. (2010). Response of Onion (Allium cepa var. cepa) to Combined Application of Farmyard Manure and Inorganic Nitrogen and Phosphorus Fertilizers at Alage, Ethiopia. An M.Sc. Thesis submitted to School of Graduate Studies, Haramaya University, Ethiopia. Pp 26-40.

Metasebia, M., \& Shimelis, H. (1998). Proceeding of the $15^{\text {th }}$ Annual Research and Extension Review Meeting, 2 April 1998. Alemaya Research Centre. Alemaya University of Agriculture, Ethiopia. Pp 216-235.

Miller, R.W., \& Donanue, R.L. (1995). Soils in our environment. $7^{\text {th }}$ Edition. Prentice Hall, Englewood cliff. Pp 261-281. 
M'Nen. (1992). Stratification of Fertilizer Trials in Ethiopia. Report. GCPF/ETH/09/ITA, FAO, Rome.

Morris, M., Kelly, V.A., Kopicki, R.J., \& Byelee, D. (2007). Fertilizer Use in African Agriculture: Lessons Learned and Good Practices Guidelines. World Bank, Washington, D.C. Pp 144. http://dx.doi.org/10.1596/978-0-8213-6880-0

Muhammad, A., Gambo, B.A., \& Ibrahim, N.D. (2011). Response of Onion (Allium cepa L.) to Irrigation Intervals and Plant Density in Zuru, Northern Guinea Savanna of Nigeria. Nigerian Journal of Basic and Applied Sciences. 19(2), 241- 247.

Murage, E.W., Karanja, N.K., Smithson, P.C., \& Woomer, P.L. (2000). Diagnostic indicators of soil quality in productive and non-productive smallholders' fields of Kenya's Central Highlands. Agriculture, Ecosystems and Environment, 79, 1-8. http://dx.doi.org/10.1016/ S0167-8809(99)00142-5

Murashkina, M., Southard, R.J., \& Pettygrove, G.S. (2006). Potassium Fixation in Silt, Sand and Clay Fractions of Soils Derived from Granitic Alluvium of the San Joaquin Valley, California. The $18^{\text {th }}$ World Congress of Soil Science (July 9-15, 2006) at Philadelphia, Pennsylvania, USA. (http://acs.confex.com/crops/wc2006/techprogram/index.html)

Nagaich, H.N., Trivedi, S.K., \& Lekgi, R. (2003). Effect of sulphur and potash on growth, yield and quality of garlic (Allium sativa Linn.). Scientific Horticulture, 8, 143-147.

Nonnecke, I.L. (1989). Vegetable Production, New York. Pp 657.

Norman, M., Rearsonand, C., \& Searle, P. (1995). The Ecology of Tropical Food Crops. Cambridge University Press, Cambridge. http://dx.doi.org/10.1017/cbo9781139172479

Palm, C.A., Myers, R.J.K., \& Nandwa, S.M. (1997). Combined use of organic and inorganic nutrient source for soil fertility maintenance and replenishment. In: Buresh et al., (Eds.). Replenishing soil fertility in Africa. Special publication No. 51. Wisconsin, USA. Pp 193217.

Peiris, K.H.S., Mallon, J.L., \& Kays, S.J. (1997). Respiratory rate and vital heat of some specialty vegetables at various storage temperatures. Horticulture Technology, 7, 46-49.

Pire, R., Ramirez, H., Riera, J., \& Gomez, T.N. (2001). Removal of N, P, K and Ca by an onion crop (Allium cepa L.) in a silty-clay soil, in a semiarid region of Venezuela. Acta Horticulturae, 555, 103-109. http://dx.doi.org/10.17660/ActaHortic.2001.555.12

Poornima, K.S. (2007). Effect of Potassium and Sulphur on Yield and Quality of Onion and Chilli Intercrops in a Vertisols. An M.Sc. Thesis submitted to the University of Agricultural Sciences, Dharwad. Pp 46-94.

Potgieter, J. (2006). Verbal communication on macro-elements application time. Researcher, Limpopo Department of Agriculture. April 2006.

Rabinowitch, H.D., \& Brewster, J.L. (1990). Onions and Allied Crops. Vol. II. CRC press, Boca Raton. Florida. Pp 320. 
Ramirez-Moreno, E., Cantwell, M.I., \& Mercado-Silva, E. (2001). Physiology and quality of freshpeeled garlic cloves stored in air and CA. Proceedings on Alliums 2000, Third International Symposium on Edible Alliaceae, Athens, GA. Pp 196-198.

Randle, W.M., \& Lancaster, J.E. (1995). Quantifying onion flavor compounds responding to sulphur fertility, sulphur increases level alk(en)yl cysteine sulfoxides and biosynthetic intermediates. American Society for Horticultural Science. 120, 1075-1081.

Rao, M.R., Kwesiga, N.A., Duguma, F.B., Frazel, S., Jama, B., \& Buresh, R. (1998). Soil fertility Replenishment in Sub-Saharan Africa. In: Agro forestry today (Debra London Ed.) International Center for Research in Agro forestry (ICRAF) UK. 10(2), 2 -5.

Raun, W.R., \& Johnson, G.V. (1999). Improving nitrogen use efficiency for cereal production. Agronomy Journal. 91, 357-363. http://dx.doi.org/10.2134/agronj1999.000219620091000 $30001 \mathrm{x}$

Rice, R.P., Rice, L.W., \& Tindall, H.D. (1990). Fruits and vegetable production in warm climates. Macmillan Education Ltd. Hong Kong. Pp 486.

Rizk, F.A. (1997). Productivity of onion plant (Allium cepa L.) as affected by method of planting and NPK application. Egyptian Journal of Horticulture. 24(2), 219-238.

Rubatzky, V.E., \& Yamaguchi, M. (1997). World Vegetables, Principles, Production and Nutritive Values. Second edition. Chapman and Hall. International Thomson publishing, New York, USA. Pp 843.

Ruthford, P.P., \& Whittle, R. (1982). The carbohydrate composition of onions during long-term cold storage. The Journal of Horticultural Science. 57, 349-356. http://dx.doi.org/10.1080/ 00221589.1982 .11515063

Ryan, J. (2008). A Perspective on balanced fertilization in the Mediterranean Region. Turkish Journal of Agriculture and Forestry. 32, 79-89.

Salama, A.M., Hicks, J.R., \& Nock, J.F. (1988). Respiration and fresh weight of onion bulbs as affected by storage temperature, humidity and maleic hydrazide. The Journal of Tropical Forest Science. 27, 233-238.

Salo, T., Suojala, T., \& Kallela, M. (2002). The effect of fertigation on yield and nutrient uptake of cabbage, carrot and onion. Acta Horticulturae, 571, 235-241. http://dx.doi.org/10.17660/ ActaHortic.2002.571.28

Salomon, R. (2002). Virus diseases in garlic and the propagation of virus free planting. Pp. 311327. In: Rabinowitch, H.D., Currah L. (Eds.). Allium crop sciences: Recent advances. CAB International, Wallingford, UK. http://dx.doi.org/10.1079/9780851995106.0311

Samuel, G. (1981). Uptake and Response of Durum Wheat (Triticum durum. Desf) to N and P Fertilization on Koticha and Gombore Soils of Ada'a Plains. An M.Sc. Thesis Submitted to College of Agriculture, Alemaya University, Ethiopia. Pp 98.

Satti, S.M.E., \& Lopez, M. (1994). Effects of Storage Temperature on Growth and Bulb Formation in four Garlic (Allium sativum L.) Cultivars. Pakistan Journal of Botany. 26(1), 161-165. 
Shalini, S.B., Channal, H.T., Hebsur, N.S., Dharmatti, P.R., \& Sarangamath, P.A. (2002). Effect of integrated nitrogen management on nutrient uptake in Knolkhol, yield and nutrient availability in the soil. Karnataka Journal of Agricultural Sciences. 15(1), 43-46.

Shock, C.C., Feibert, E.B.G., \& Saunders, L.D. (1998). Onion yield and quality affected by soil water potential as irrigation threshold. HortScience, 33, 1188-1191.

Shrestha, H. (2007). A plant monograph on onion (Allium cepa L.). The School of Pharmaceutical and Biomedical Sciences, Pokhara University Simalchaur, Pokhara, Nepal.

Sims, W.L., Davis, U.C., Little, T.M., Emeritus, A., \& Voss, R.E. (2003). Growing Garlic in California. UC Davis, Vegetable Research and Information Center, 2003. (http://vric. ucdavis.edu/)

Singh, S.P., \& Verma, A.B. (2001). Response of onion (Allium cepa L.) to potassium application. Indian Journal of Agronomy. 46, 182-185.

Stork, P.O., Potgieter, J.P., Van Den Heever, E., \& Niederwieser, J.G. (2004). Garlic Production, Guide to Garlic Production in South Africa, Agricultural Research Council- Vegetable and Ornamental Plant Institute, Roodeplaat, Pretoria.

Surendra, S. (2008). Effect of sulphur on yields and S uptake by onion and garlic grown in acid alfisol of Ranchi. Agricultural Science Digest. 28(3), 189-191.

Teklu, E., \& Teklewold, H. (2009). Agronomic and economic efficiency of manure and urea fertilizers use on Vertisols in Ethiopian Highlands. Agricultural Sciences. 8(3), 352-360. http://dx.doi.org/10.1016/s1671-2927(08)60219-9

Tesfaye, A., Githiri, M., Dereraand, J., \& Debele, T. (2011). Subsistence farmers' experiences and perceptions about soil and fertilizer use in western Ethiopia. Journal of Applied Science and Technology. 2(2), 61-74.

Tilahun, H., Teklu, E., Michael, M., Fitsum, H., \& Awulachew, S.B. (2011). Comparative Performance of Irrigated and Rain-fed Agriculture in Ethiopia. World Applied Sciences Journal. 14 (2), 235-244.

Tisdale, S.L., \& Nelson, W.L. (1985). Soil fertility and fertilizers, $3^{\text {rd }}$ Ed. Macmillan Publishing Co. Inc., New York and Collico-Macmillan Publishers, London.

Tisdale, S.L., Nelson, W.L., Beaton, J.D., \& Halvin, J.L. (1993). Soil Fertility and Fertilizers (5 ${ }^{\text {th }}$ Ed), Macmillan Publishing Company, New York.

Vitousek, P.M., Aber, J.D., Howarth, R.W., Likens, G.E., Matson, P.A., Schindler, D.W., Schlesinger, W.H., \& Tilman, D.G. (1997). Human alternation of the global nitrogen cycle: sources and consequences. Ecological Applications. 7, 737-750.

Vlek, P.L.G. (1990). The role of fertilizers in sustaining agriculture in sub-Saharan Africa. Fertilizer Research. 26, 327-339. http://dx.doi.org/10.1007/BF01048771 
Wakene, N., Kefalew, N., Friesen, D.K., Ronson, J. \& Abebe, Y. (2002). Determination of Optimum FYM and NP fertilizers for maize on farmer's fields. Proceedings of the Seventh Eastern and Southern Africa Regional Maize Conference, Nairobi, Kenya

Yohannes, U. (1994). The effect of nitrogen, phosphorous, potassium, and sulphur on the yield and yield components of Enset (Ensete ventricosum W.) in southeast Ethiopia. Doctoral dissertation. Institute of Plant nutrition, Faculty of Agriculture. Justus Liebig University, Giessen, Germany.

Zhou, Y., Wang, D., Zhu, J., Liu, Q., \& Fan, M.X. (2005). The role of sulfur fertilizers in balanced fertilization. In: De Kok L.J., Schnug E. (eds.), Proceedings of the $1^{\text {st }}$ Sino-German Workshop on Aspects of Sulphur Nutrition of Plants, 23-27 May 2004 in Shenyang, China, Landbauforschung Völkenrode, Special Issue 283. Pp 171-176. 